\title{
A MUNKAHELYI EGÉSZSÉGPROGRAMOK ÉRTÉKTEREMTÉSÉNEK MÉRÉSI LEHETŐSÉGEI
}

A fluktuáció, a hiányzás és a kimerülten való munkavégzés sok kárt okoz a cégeknek. E veszteségek csökkentésének egyik lehetséges eszköze a vállalati egészségprogram működtetése. Az ilyen kezdeményezések népszerűségét mutatja, hogy míg 2008-ban globálisan a multinacionális vállalatok 34 százaléka indított ilyen programokat, 2014-ben már 56, 2016-ban pedig 69 százalékuk. De mennyire sikeresek ezek a programok? Hogyan mérhető az általuk teremtett érték? E cikk nemzetközi irodalomkutatásra építve az egészségprogramok hatásainak mérési lehetőségeit tekinti át. Ez alapján a hatékonyságot három különböző szemléletben szokták megközelíteni. A pénzben jól mérhető vállalati előnyökre fókuszáló ROI-szemlélet mellett mind elterjedtebb a programok dolgozókra gyakorolt hatását mérő VOI-megközelítés. Ugyanakkor makroszinten a társadalmi hatásokat is lefedő, de csak pénzben mérő SROI-módszertan használata lehet a célravezető.

Kulcsszavak: ROI, VOI, SROI, hatékonyság, vállalat, egészség

A WHO már 1950-től foglalkozik a munkahelyi egészség témájával, kiemelve: nemcsak a munka és a munkahely hat a dolgozók fizikai és mentális egészségi állapotára, hanem a munkavállalók egészségi állapota is hat a vállalatra és annak üzleti teljesítményére. Majd húsz évvel később, az 1970-es években indultak el az első munkahelyi egészség- és mozgásprogramok Ausztráliában és az Egyesült Államokban (Chu et al., 1997). Európában e tekintetben a skandináv országok az élenjárók (Eichberg, 2009).

A munkahelyi egészségfejlesztés a Munkahelyi Egészségfejlesztés Európai Hálózatának (ENWHP) 1997-es, Luxemburgi Deklarációban meghatározott definíciója szerint: ,a munkaadók, a munkavállalók és a társadalom valamennyi olyan közös tevékenységét jelenti, amely a munkahelyi egészség és jól-lét javítására irányul. A cél eléréséhez három eszközrendszer együttes alkalmazása szükséges: a munkaszervezet javítása, az aktív dolgozói részvétel biztosítása és támogatása, valamint az egyéni kompetencia erősítése" (ENWHP, 1997, p. 2.). Tíz év múlva, 2008-ban, a szöuli XVIII. Munkahelyi Biztonság és Egészség Kongresszuson a résztvevők kimondták: mindenkinek alapvető emberi joga a biztonságos és egészséges munkahely (WHO, 2010).

Az „elsőgenerációs” programok jellemzően dohányzásellenes leszoktató programok voltak. A „másodikgenerációs" programok a kockázati tényezők felmérésére koncentráltak, míg a „harmadikgenerációsaknál” előkerült a teljes testi-lelki jól-lét kérdése. Ugyanakkor még a „harmadikgenerációs” programok is csak egyéni szinten gondolkodtak.

Ezzel szemben a manapság aktuális „,negyedikgenerációs" programok már a szervezet szintjén kell, hogy működjenek. Chu és társai (1997) kiemelik: magában a vállalati kultúrában kell meghonosítani az egészséget, amikor munkahelyi egészségprogramok bevezetéséről van szó, legyen ez akár dohányzás, táplálkozás, mozgás, lelki egészségfejlesztő vagy stresszcsökkentő programelem, netán ezek kombinációja.
Vaughan-Jones és Barham (2009) szerint az ébren töltött időnk 37 százalékát mintegy 40 éven keresztül a munkahelyünkön töltjük, ezért az kiváló terep az egészséges életmódra és a mozgásra neveléshez. Dongen és társai (2011) aláhúzzák: a szemléletformálásban nagy szerepe lehet a munkahelynek, az ottani „társadalmi-szociális” közegnek.

Ráadásul azon felül, hogy alapvető emberi jogunk a biztonságos és egészséges munkahely, tisztán üzleti szempontok alapján is megéri költeni munkahelyi egészségfejlesztésre (Szabó, 2013). Ezt egyre több vállalatnál ismerik fel. A Xerox (2016) adatai szerint globálisan 2008-ban a multinacionális vállalatok 34 százaléka indított egészségprogramokat, 2014-ben már 56, 2016-ban 69 százalékuk. Manapság a világ munkaadóinak 74 százaléka úgy gondolja, hogy a munkahelyi jól-lét kulcsfontosságú elem a munkavállalók megtartásában, teljesítményében, összességében a munkavállalói értékteremtésben.

A „44 legegészségesebb amerikai vállalat” programjait áttekintve az érintett cégek a mozgás, a táplálkozás és a lelki egészség fejlesztésére koncentráltak egészségprogramjaikban (Thorpe, 2015). A Virgin Pulse (2016) felmérése szerint 2016-ban leginkább a mozgásprogramok, a lelki egészséggel kapcsolatos programok és a dohányzásról leszoktató programok fordultak elő vállalati egészségprogramok részeként. A legnagyobb növekedést 2015-höz képest a helyi edzőtermek létesítésében tapasztalták. Egy évvel később, 2017-ben a mentális egészséggel kapcsolatos programok indítása volt a leggyakoribb, ezen a területen mérték a legnagyobb növekedést az előzó évhez képest (Virgin Pulse, 2017). Aldana (2018a) szerint a vállalatok egészségfejlesztési ráfordításai 2018-ban nemzetközi szinten fejenként évi 150 és 1200 dollár között mozogtak.

Össztársadalmi szinten a krónikus betegségek miatt az egészségügyi kiadások egyre emelkednek. Egyre több a túlsúlyos, az alkoholhoz, droghoz nyúló vagy éppen a fizikailag inaktív munkavállaló. Ezek a káros „,szokások” nagyrészt a sok stressz számlájára írhatók. Pfeffer (2018) állítása szerint a munkahely, a munkahelyi környezet 
okozza számunkra a stressz legnagyobb részét, a jelenleg „uralkodó” munkahelyi kultúra a munkavállalók fizikai és mentális jól-léte ellen hat. Pfeffer (2018) ezt a jelenséget társadalomszennyezésnek (social pollution) nevezi. Ahogy a környezetszennyezés ellen sokat harcoltak egyéni, vállalati és társadalmi szinten is, úgy a társadalomszennyezés ellen is tenni kell, mindhárom szinten. Foglalkozni kell a dolgozók munkavégző képességének fenntarthatóságával, amihez nem elég egy-egy fitneszterem vagy jógaóra, hanem komplex megoldásra van szükség. A vállalati állampolgársági (corporate citizenship) megközelítések szerint a vállalatok társadalmi szerepének értelmezésekor tekintetbe kell venni a társadalmi, kulturális közeget is, amelyben müködnek, és az azokra való visszahatásokat is (Géring, 2014).

Az EU-OSHA (2018) becslései szerint a munkával összefüggő betegségek évente mintegy kétszázezer halálesetet okoznak Európában. A munkahelyi egészségkárosodások és sérülések miatti költségek évente 476 milliárd euróra rúgnak az Európai Unióban, ami folyó áron a 2016os teljes uniós GDP több mint 3,2 százaléka (Eurostat, 2018), a magyar GDP-nek pedig több mint négyszerese (KSH, 2018). E költségek csökkenthetők lennének megfelelő munkahelyi egészségvédelmi stratégiákkal és gyakorlatokkal, például egészségprogramok bevezetésével. A hasznok tehát nemcsak az egyén és a vállalat, de a társadalom szintjén is jelentősek lehetnek.

A munkahelyi egészségfejlesztésről, annak hatásairól és a hatások méréséről itthon rendkívül kevés vizsgálat született. Ennek egyik oka, hogy Magyarországon csak az utóbbi évtizedben kezdett megélénkülni a terület: a legrégebben müködő program sincs 15 éves (Coca-Cola, 2013). Összességében elmondhatjuk, hogy miközben néhány, jellemzően multinacionális vállalat (Unilever, Coca-Cola) futó programjaival élen jár a területen, alapjában véve Magyarországon komoly fejlesztésre szorul a terület. Egy 2010-es, 709 régiós vállalatot (ezek harmada magyar cég volt) felmérő MGYOSZ-kutatás (2010) szerint a munkahelyi egészségvédelem területén a leginkább (32 százalékban) az ergonómiai fejlesztések jelentek meg, miközben a cégek több mint 40 százaléka semmilyen munkahelyi egészségfejlesztési programot sem müködtetett. Egy Szinapszis (2013) kutatás eredményei szerint az itthon megkérdezett 400 munkavállaló mindössze 17 százaléka vett részt rendszeres és kötelező programokban. E programok hatásának méréséről pedig egyelőre szó sincs.

\section{Sikeres vállalati egészségprogramok és hatásaik}

A WHO (2010) útmutatása szerint a sikeres programokhoz a legfontosabb érintetteket, véleményvezéreket kell megnyerni. Ez tökéletesen összecseng az ugyancsak a vállalati kultúrába való beépülést sikerkritériumnak tekintő vállalati kockázatkezelési (ERM, enterprise risk management) programok tapasztalataival (Oliveira et al., 2018). Szükséges a felső vezetők támogatása is, majd ösz- sze kell állítani egy csapatot, amely a munkahelyi egészségfejlesztő programért felelős. Az ő feladatuk a támogató környezet kialakítása, a kommunikáció, az ösztönzés és az oktatás-képzés mellett a munkatársak minél szélesebb körének bevonása is. Különböző szürésekkel, tesztekkel fel kell mérni, hol áll a szervezet induláskor, milyen az alkalmazottak testi-lelki állapota, hogyan táplálkoznak, mennyit mozognak, hányszor hiányoznak, milyen gyakran betegek. Ez a lépés ugyancsak jól párhuzamba hozható az ERM-rendszerek kockázati felmérés lépésével.

Azt is meg kell határozni, hová akarunk eljutni. A sok lehetséges terület közül ki kell választanunk, mi az, ami a vállalatunk és munkavállalóink szempontjából a legfontosabb. Mérlegelnünk kell a kockázatokat, a költségeket, a lehetőségeket is a tervezés során. Szükséges egy 3-5 év időtávra vonatkozó egészségterv összeállítása is, amelyet érdemes lebontani éves tervekre, kisebb programokra. A konkrét folyamatokat, felelősöket, célokat, költség- és időtervet is meg kell határozni - megint csak nagyon hasonlóan az ERM-rendszerek bevezetésénél javasoltakhoz.

A munkaadóknak és a munkavállalóknak sokkal inkább együtt kell dönteni a célokról, az elérés mikéntjéről, mint ezeket felülről meghatározni, mert egyrészt a munkavállalókért, a munkavállalók jól-létéért születnek a programok, másrészt azon rendszerek, intézmények, amelyek élvezik a munkavállalók bizalmát és - kapcsolódva más rendszerekhez (például képzés-fejlesztés) - növelhetik a motivációt és az elkötelezettséget (Bácsi, 2017).

Napjaink emberierőforrás-menedzsment kihívásaira is jó válasz lehet egy helyesen összeállított program. Ugyanis kifejezetten az Y-generációnak (azon belül is az egyensúlykeresők csoportjának) nagyon értékes a munka és a magánélet egyensúlya, a munka minősége, a munka környezete (Meretei, 2017). A BCG 2018-as kutatásai szerint a magyar dolgozók számára a munka és magánélet egyensúlya, valamint a kollégákkal való jó kapcsolat a legfőbb, amikor új munkahelyet választanak. A dolgozók számára tíz legfontosabb pontból hat a munkahelyi légkörhöz, a közérzetükhöz kapcsolódik.

Természetesen a terveket végre is kell hajtani, amihez a résztvevőknek rendszerint folyamatosan támogatást, segítséget kell nyújtani. Nagyon fontos elem az értékelés: a megvalósult programokat folyamatosan figyelni kell, hogy nyomon kövessük a változást. Amennyiben szükséges, a programot át kell alakítani és tovább kell fejleszteni, kiterjeszteni (WHO, 2010), éppen úgy, ahogy ezt egy ERM-rendszernél is tennék (International Organization for Standardization, 2018).

A vállalati egészségprogramok kapcsán a szakirodalomban megjelenő sikertényezőket az 1. táblázat tekinti át. A legfontosabb, a legtöbb szerző által sikertényezőként említett a vezetői elköteleződés. Enélkül el sem tud indulni egy egészségprogram, hisz az anyagi és emberi erőforrások biztosítása a vezetők kezében van. 
1. táblázat

A vállalati egészségprogramok sikertényezői

\begin{tabular}{|c|c|c|c|c|c|c|c|c|c|}
\hline & 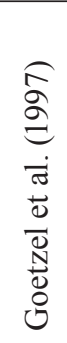 & 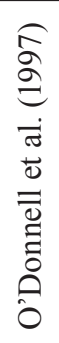 & 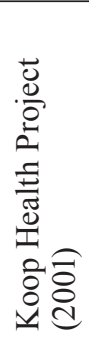 & 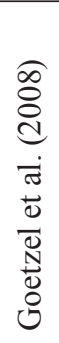 & 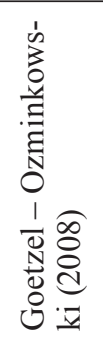 & 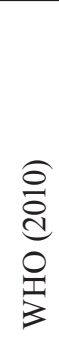 & 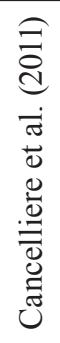 & 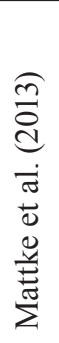 & $\begin{array}{l}\text { ñ } \\
\stackrel{d}{d} \\
\text { ñ } \\
\text { A }\end{array}$ \\
\hline Szervezeti, vezetői elköteleződés & $\boldsymbol{V}$ & $\boldsymbol{V}$ & $\checkmark$ & $\boldsymbol{V}$ & & $v$ & $v$ & $\checkmark$ & $\boldsymbol{V}$ \\
\hline Üzleti és etikai célok meghatározása & & & $\checkmark$ & & & & & $\checkmark$ & \\
\hline Üzleti célokhoz, stratégiához, kultúrához illeszkedés & & $\checkmark$ & $\checkmark$ & & $v$ & $\checkmark$ & & $\checkmark$ & $\checkmark$ \\
\hline Hatékony tervezés & & $\checkmark$ & & & & $\checkmark$ & & & $\checkmark$ \\
\hline Támogató környezet & & & & & $\checkmark$ & $\checkmark$ & $\checkmark$ & & $\checkmark$ \\
\hline Munkavállalók bevonása (már a célok meghatározásánál is) & & $\checkmark$ & & & $\checkmark$ & $\checkmark$ & & $\checkmark$ & $\checkmark$ \\
\hline Hatékony kommunikáció & & $\checkmark$ & $\checkmark$ & & $\checkmark$ & & & $\checkmark$ & $\checkmark$ \\
\hline Ösztönzők & $\checkmark$ & $\checkmark$ & & $\checkmark$ & & & & & $\checkmark$ \\
\hline Hozzáférhetőség, személyre szabott programok & & $\checkmark$ & & & & $\checkmark$ & $\checkmark$ & $\checkmark$ & \\
\hline Szűrések és priorizálás & $\checkmark$ & $\checkmark$ & & $\checkmark$ & & $\boldsymbol{V}$ & $\boldsymbol{V}$ & & \\
\hline Hatékony megvalósítása a programoknak & $\checkmark$ & $\nu$ & & $\checkmark$ & & & & $v$ & $\boldsymbol{V}$ \\
\hline Folyamatos értékelés, ellenőrzés & $\checkmark$ & $\checkmark$ & & $\checkmark$ & $\checkmark$ & $\boldsymbol{V}$ & & $\checkmark$ & $\checkmark$ \\
\hline Fejlesztés & & & & $\checkmark$ & $\checkmark$ & $\checkmark$ & & & \\
\hline
\end{tabular}

Forrás: Goetzel et al. (2007) alapján, saját kiegészítésekkel

A programok folyamatos értékelése a másik legtöbbek által fontosnak tartott sikertényező. Ami érdekes, föleg a hazai gyakorlatot megnézve, hogy elméletben fontos az értékelés, a mérés, de gyakorlatban nem valósítják meg, jellemzően még a Legfittebb Munkahely felméréseken győztes vállalatok sem (Szabó, 2018). Egyetlen győztes vállalatnál volt csak ROI-módszertanra építő értékelés. Ugyanakkor nemzetközi szinten is bőven vannak hiányosságok a programok értékelésében, mérésében. IFEBP (International Foundation of Employee Benefit Plans) adatok szerint a megkérdezett vállalatok 28 százaléka mér csak bármilyen megtérülést az egészségprogramoknál. A Healthiest Employers Award résztvevőinél ugyanez az arány 23 százalék (Springbuk, 2018). Mindezek miatt még elméleti szinten is fontos a mérés lehetőségeivel foglalkozni. Magyarországon ez a terület még szinte teljesen kiaknázatlan.

A kutatások szerint az egészségesebb munkavállalók már rövid távon is jobb fizikai és szellemi teljesítményre képesek, hatékonyabbak, termelékenyebbek, elégedettebbek, motiváltabbak és lojálisabbak. Az a dolgozó, aki úgy érzékeli, hogy a munkaadója törődik az egészségével és a jól-létével, 38 százalékkal elkötelezettebb lesz, mint az, aki úgy érzékeli, hogy ez a faktor nincs meg (Hackbart et al., 2015). Az Aon Hewitt tanácsadó cég 2017-es eredményei szerint (Hewitt, 2017) a világ munkavállalóinak 63 százaléka érzi magát elkötelezettnek, az európaiaknál ez az arány mindössze 58 százalék. A munkahelyi egészségprogram javíthatja az egyéni, a vállalati, a regionális és a makroszintü versenyképességet is.
Aldana (2018b, 2018c) rámutat: az egészségprogramok négyféle módon is értéket teremtenek a vállalatnak. (1) A programok javítják az alkalmazottak egészségtudatosságát, így egészségesebben élnek, ezáltal csökkentik az egészségügyi kockázatokat, egészségügyi kiadásokat mind a vállalatnál, mind egyéni szinten. Ozminkowski et al. (2016) kutatásai szerint is ez a legfőbb oka az egészségprogramok indításának. A program indítása utáni első hat hétben történik általában a legjelentősebb változás, és azon munkavállalók, akik 18 hónap után is kitartanak a programban, már nem térnek vissza a régi, egészségtelenebb életmódjukhoz.

(2) E programok azáltal növelik a termelékenységet, hogy csökkentik a hiányzást, és még inkább úgy, hogy csökkentik a presenteeism jelenségét (azaz a nem teljes értékü munkahelyi jelenlétet, amikor a munkavállalók mentálisan vagy fizikailag kimerült állapotban, betegen végzik a munkájukat). Egyre inkább elötérbe kerül, hogy a presenteeism miatti termelékenységkiesés sokszorosa a hiányzások miatti kiesésnek. Ráadásul a dohányzó munkavállalók körében 28 százalékkal, az egészségtelenül táplálkozók körében 66 százalékkal, a mozgásszegény életmódot folytató munkavállalók körében 50 százalékkal nagyobb az esélye a presenteeismnek, mint az egészségesen élőknél (Aldana, 2018b). Az előbbiek mellett a programoknak köszönhetően (3) kisebb lesz a fluktuáció, azaz könnyebb a munkaeröt megtartani, sőt vonzani is és (4) javul a morál, a hangulat is. 
Nemzetközi kutatások eredményeit összegezve (2. táblázat) Aldana (2018b, 2018c) megállapításaival egybevágóan, de az egyes értékteremtő tényezők megjelenéséhez időt is kötve a Tasmania kutatócég (2012) szerint, ha a vállalat elindít egy mozgásprogramot, amelynek keretében a kollégák együtt sportolnak, már néhány hónapon belül is megváltozhat a munkahelyi légkör, javul a morál, az elköteleződés, a csapat összetartóbb lesz. A program elindítása után 1-2 évvel lesz érzékelhető a magasabb teljesítmény, nagyobb termelékenység, a vállalati imázs pozitív változása és a munkavállalók testi-lelki egészségtudatosságának és elégedettségének jelentős növekedése, így szignifikánsan csökken a fluktuáció. Nagyjából 3-5 év után jelentősen csökkennek a munkahelyi sérülések, balesetek, betegségek, hiányzások, valamint a presenteeism, továbbá az emberekbe fektetett képzési, fejlesztési kiadások is megtérülnek (Tasmania, 2012).

\section{2. táblázat}

A munkahelyi mozgásprogramok hatásai

\begin{tabular}{|l|l|l|}
\hline \multicolumn{1}{|c|}{$\begin{array}{c}\text { Néhány } \\
\text { hónapon belül }\end{array}$} & \multicolumn{1}{|c|}{$\mathbf{1 - 2}$ év alatt } & \multicolumn{1}{c|}{$\mathbf{3 - 5}$ év után } \\
\hline $\begin{array}{l}\text { Szorosabb } \\
\text { elkötelezödés }\end{array}$ & $\begin{array}{l}\text { Magasabb } \\
\text { termelékenység } \\
\text { és teljesítmény }\end{array}$ & $\begin{array}{l}\text { Kevesebb } \\
\text { munkahelyi } \\
\text { sérülés }\end{array}$ \\
\hline $\begin{array}{l}\text { Jobb munkahelyi } \\
\text { morál }\end{array}$ & $\begin{array}{l}\text { Megnövekedett } \\
\text { munkaerö- } \\
\text { megtartás és } \\
\text { vonzás }\end{array}$ & $\begin{array}{l}\text { Ritkább betegség, } \\
\text { hiányzás }\end{array}$ \\
\hline $\begin{array}{l}\text { Erösebb } \\
\text { csapatszellem, } \\
\text { közösség- } \\
\text { formálás }\end{array}$ & Pozitív imázs & $\begin{array}{l}\text { Kevesebb } \\
\text { presenteeism }\end{array}$ \\
\hline & $\begin{array}{l}\text { Jobb egyéni } \\
\text { egészség- } \\
\text { tudatosság }\end{array}$ & $\begin{array}{l}\text { A képzések, } \\
\text { fejlesztések } \\
\text { javuló hozamai }\end{array}$ \\
\cline { 2 - 3 } & $\begin{array}{l}\text { Nagyobb } \\
\text { elégedettség }\end{array}$ & \\
\hline
\end{tabular}

Forrás: Tasmania (2012, p.15.)

Goetzel (2016) szerint is olyan üzletileg fontos tényezőket is értékelni kell az egészségprogramoknál, mint a tehetségek vonzása, megtartása, a munkahelyi morál, az elkötelezettség, a rugalmasság, az elégedettség. 2014-ben globális szinten a morál és az elkötelezettség növelése voltak a fó motiválók, amelyek miatt egészségprogramokat indítottak a cégek. 2017-ben is az elköteleződés növelése volt globálisan a programok indításának fö oka (Virgin Pulse, 2017).

\section{A hatásmérés módszertani megközelítései}

A szakirodalomban az egészségprogramok teljesítménymérése kapcsán három szemléletet azonosíthatunk. A mérés során (1) koncentrálhatunk a munkaadónál jelentkező, pénzben jól mérhető előnyökre (ROI- szemlélet), (2) vizsgálhatjuk az egyének és csoportok szintjén megjelenő, sokszor szubjektív és nehezen mérhető változásokat is (VOI-szemlélet) vagy (3) becsülhetjük a társadalom számra elérhető előnyöket is (SROI). Ezek a szemléletek eltérnek a vizsgálatba vontak körében, a felhasznált mutatókban, a célokban és eszközökben is. Mást tekintenek értéknek és más szereplő szemszögéből igyekeznek azt nyomon követni. Így lényegesen eltérő megközelítéseket jelentenek és gyökeresen eltérö eredményre vezethetnek anélkül, hogy ellentmondanának egymásnak.

\section{Return on Investment (ROI) szemlélet}

E szemlélet a nevét a vállalati pénzügyekben széles körben használt tőke arányos megtérülés (Return on Investment - ROI) mutatóról kapta. Ez az elnevezést azonban némileg félrevezető lehet. A pénzügyekben a ROImutató gyakran használt definíciója szerint az adott év adózatlan müködési eredményét (bevétel-ráfordítás) és a müködésbe lekötött (idegen és saját) tőke összességét vetjük össze (Brealey - Myers - Allen, 2011, p. 711.). Ezzel szemben a hatékonyságmérésben alkalmazott ROI esetében az elért hozamok (output) és a létesítési befektetés (input) különbségét a befektetés nagyságával kell elosztani. Ez a számítási megoldás inkább a nettó hozam és a befektetett tőke hányadosaként definiált jövedelmezőségi index (profitability index) megközelítésével rokon. A szakirodalomban a leggyakrabban használt képlet szerinti számítása a következő.

$$
\mathrm{ROI}=\frac{\text { Időszaki pénzbeli hasznok,megtakarítások }}{\text { Időszaki költségek }}
$$

Ugyanakkor lényeges eltérés a pénzügyi szemlélethez képest, hogy a széles körben használt teljesítmény ROI számviteli adatokra épít ugyan, de nem igazodik a tulajdonosi értékteremtés mérésénél megkövetelt cash flow szemlélethez. Ráadásul mindig csak egyetlen időszak folyó müködési adatai szerepelnek a számlálóban, figyelmen kívül hagyva az esetleges korábbi tartós befektetéseket. Emiatt az egészségprogramokról szóló szakirodalomban használt megközelítés teljesen elmossa a folyó ráfordítások és a tőke közti különbséget (lényegében a tőke viszsza nem nyerhetőségét feltételezi), a kifizetések időzítését (időértékét) pedig egyáltalán nem veszi figyelembe.

Tovább nehezíti az eredmények összevetését, hogy az egészségprogramok mérésénél semmiféle egységesen elfogadott és alkalmazott definíciót sem találunk. A számlálóban megjelenhet a bevétel vagy megtakarítás (főként Észak-Amerika), de a nettó nyereség (Európa és Ausztrália) is; a nevezőben a ráfordítás, a befektetett tőke, vagy akár ezek összege; az átfogott időtartam néhol egy év, másutt azonban a program teljes hossza, amely lehet több és kevesebb is, mint 12 hónap.

A néhány éves programoknál sokszor a pénz időértékétől eltekintenek, s tovább nehezíti az eredmények értelmezését és összevetését, hogy nagyon sokszor az alkalmazott képlet ismertetése teljesen kimarad a cikkekböl. Hiába tehát a megközelítés fö erejének számító pénzbeli mérés lehetősége, ha azt legtöbbször nem a pénzügy szabályait követve végzik. Dongen et al. (2011) is megjegyzik, hogy az egyes tanulmányokban nem egységes módon számítják a ROI-t, így nehéz az összehasonlítás, és ők maguk igyekeztek a kutatások adatait standardizálni. A WHAA 
(2016) szerint a ROI-t számos tényező befolyásolhatja, amelyeket nem biztos, hogy mindig figyelembe vesznek, és amelyek vállalatról vállalatra különbözhetnek. Ilyenek lehetnek a részvételi arány, a kockázati tényezők jelenléte, gyakorisága, a kutatás elméleti megalapozottsága, a munkavállalói igényekhez való alkalmazkodás milyensége, a program személyessége, az IT minősége és alkalmazása, valamint az időtényező.

Csak e módszertani korlátok ismeretében érdemes vizsgálni a szakirodalom igencsak változatos ROI eredményeit (Aldana, 2001; Goetzel et al., 2008; Baicker et al. 2010; Casey, 2017; Dongen et al., 2011, Henke et al., 2011). Az Amerikai Kereskedelmi Kamara jelentése (SFM, 2017) szerint például a jól megtervezett programoknál 1 dollár hozama 2-9 éves időtávon 1,50 dollártól több mint 3 dollárig terjed.

Goetzel et al. (2008) szerint hároméves időtávon minden vállalati egészségprogramra költött dollár 1,4-4,7 dollárt hoz. Casey (2017) szerint a kutatásba bevont vállalatok 30 százalékánál 1 dollár hozama (ROI) 1-2 dollár közötti volt, 26 százalékánál 2-3 dollár közötti, 12 százalékánál 3-4 dollár közötti, míg 16 százalékánál 4 dollárnál is több.

Dongen et al. (2011) 3835 cikket átvizsgálva mindöszsze 18 olyan táplálkozás- és mozgásprogramokról szóló korábbi tanulmányt talált, amely módszertanilag megfelelö, teljes szövegü, kontrollcsoportos és primer vizsgálatra épült és vizsgálta a költséghatékonyságot is. Ezek közül 14 esetben (78 százalékban) a nettó haszon és a ROI is pozitív volt, valamint a költség-haszon arány is 1 feletti értéket vett fel.

Henke et al. (2011) a Johnson \& Johnson 1979-ben bevezetett munkahelyi egészségfejlesztési programját vizsgálta 2002 és 2008 között. Eredményei szerint minden programra fordított dollárnál 3,92 dollár hozamot tudtak kimutatni. Az átlagos éves munkavállalónkénti megtakarítás 2009-ben 565 dollár volt. Már inkább a később bemutatott VOI-megközelítést alkalmazva rámutat: a vállalat alkalmazottainál érdemben csökkent az elhízás, a magas vérnyomás, a magas koleszterinszint, a dohányzás, a fizikai inaktivitás és az egészségtelen táplálkozás gyakorisága.

Baicker et al. (2010) 22 vállalati tanulmányt átfogó elemzése szerint minden dollárral, amelyet egészségfejlesztő programra költ egy vállalat, 3,27 dollár egészségügyi kiadás és 2,73 dollár hiányzás miatti kiadás spórolható meg 2-3 éves időtávon. Dongen et al. (2011) szerint a táppénzt és a termelékenységet tekintve 1,4-4,6 dollár 1 dollár összesített hozama, a hiányzásokat tekintve pedig 2,7 dollár takarítható meg.

Aldana (2001) szerint minden dollárral, amelyet egészségfejlesztő programra költ a vállalat, átlagosan 4,3 dollárt spórolhat meg. Eredményei szerint az összes egészségügyi rizikótényező közül a túlsúly és a stressz az a két tényező, amelyek növekedése minden kétséget kizárólag növeli az egészségügyi kiadásokat és a hiányzásos napok számát.

További tanulmányok ROI-értékeinek részletes áttekintését adja Baxter et al. (2014), aki rámutat: minél jobb módszertanilag egy tanulmány, annál kisebb a kimutatott ROI. Az 1984 és 2012 között közzétett 51 tanulmány rész- letes értékelése során azt látták, hogy az idő múlásával a módszertani minőség javult. Az átlagos ROI 1,38 volt, de míg ez az érték a jó minőségű vizsgálatokban csak 0,23 volt, a közepes minőségü vizsgálatokban 0,9 , a gyenge minőségű vizsgálatokban 2,3. A randomizált kontrollvizsgálatok (RCT) negatív ROI-t mutattak, ám ezeket ritkán idézik.

\section{A VOI-szemlélet}

A VOI (Value on Investment) szemlélet lényege, hogy a mérések nemcsak a pénzbeli hasznokra, hanem a programok nyomán bekövetkező minden közvetlen megtakarítást kiváltó változó (egyfajta értékteremtő tényezői kör) alakulására koncentrálnak, a hasznok pénzbeli mérése pedig nem feltétlenül cél. Így a hatások jobban nyomon követhetőek, de sokkal nehezebb megalapozni a pénzügyi döntéseket. Nemcsak a különféle dimenziók hatásait nehéz összegezni, vagy pénzben kifejezni, de etikai kihívásokat is támaszthat, ha az egyes dolgozóknál mért előnyöket a másoknál mért negatív hatásokkal kell összevetnünk. Ha a vállalatirányításból igyekszünk párhuzamot keresni, a VOI a kiegyensúlyozott stratégiai mutatószám-rendszer (Balanced Scorecard) teljesítménymérési filozófiájához állhat a legközelebb.

A ROI- és a VOI-szemlélet egymásnak feszülése az egészségügyben koránt sem új keletü. Culyer és Chalkidou (2018) ugyanezen szembenállást illusztrálja az egészségügyi beruházások hatékonyságának megítélésére szolgáló költség-haszon elemzések (Cost-Benefit Analysis - CBA) és a költség-hatásosság elemzés (Cost-Effectiveness Analysis - CEA) összevetésével. Bár a lekötött erőforrásokat mindkét megközelítés pénzben jeleníti meg, a CBA a kimeneti oldalon is csak pénzben mér, míg a CEAkimeneteket reáliákban (egészségben leélt többlet évek száma) követi nyomon.

A szerzők rámutatnak, hogy a másutt jól használható CBA-megközelítés legfontosabb elönye, hogy közvetlen (pénzbeli) összevetésre kínál lehetőséget. Csakhogy ennek az a feltétele, hogy a jellemzően a fizetési hajlandóságra építő pénzbeli mérés kellően pontos legyen. Az olyan, pénzben nehézkesen mérhető javaknál azonban, mint az egészség, vagy az emberi élet, ez rendszerint nem áll fenn, ezért a CBA óhatatlanul pontatlanabb és torzabb lehet. Ugyanakkor a CEA hatékony használatához (alternatívák összevetéséhez) arra van szükség, hogy az adott célt vagy eredményt más módon is el lehessen érni. Az egészségügyben sokszor erre sincsen lehetőség. (Szerencsére ilyen kiélezett helyzetekkel a vállalati egészségprogramoknál kevésbé találkozhatunk, hiszen a munkatársak közérzetének, egészségi állapotának, elköteleződésének növelésére rendszerint nemcsak egy megoldás áll rendelkezésre.) Összességében Culyer és Chalkidou a CEA megközelítést látja alkalmazhatóbbnak a feltörekvő országokban, mivel a pénzbeli mérés lehetőségei jóval korlátozottabbak, a fejlett országokban végzett becslések használata pedig sokszor irreális eredményekre vezet.

Nicholson (2017) rámutat: a ROI azt jelzi, hogy pénzügyi szempontból sikeres volt-e egy adott program, de ebben a megközelítésben nehézkes a program teljes meg- 
térülésének, teljes értékteremtésének vizsgálata. Ugyanakkor Bryson et al. (2014, idézi Nicholson, 2017) szerint még mindig viszonylag kevés módszertanilag megfelelő empirikus bizonyíték van a munkavállalók jól-létének és a vállalat teljesítménynek a kapcsolatáról.

A korlátozott bizonyítékok ellenére a munkahelyi egészségfejlesztés értékteremtése legalább anekdotikus alapokon általánosan elfogadott, ahogy az is, hogy e programok célja a munkaerő termelékenységének és egészségének előmozdítása is, amelyek a vállalat teljes üzleti teljesítményéhez hozzájáruló kritikus tényezők (Martínez-Lemosm, 2014, idézi Nicholson, 2017). Újabban, bizonnyal nem kis részben a ROI számítása körüli módszertani zavar miatt is, az ilyen programok megítélésekor a cégeknél egyre kevésbé a ROI és egyre inkább az emberek visszajelzései számítanak (Nicholson, 2017).

Fritz és Richter (2018) arra tesznek javaslatot, hogy a pénzben nehézkesen mérhető hozamokat miképpen tudnák a döntéshozók mégis a ROI számításakor figyelembe venni, vagyis lényegében a CEA-szemléletben mért változókból pénzbeli hasznokat számítani. Javaslatuk szerint a hasznok pénzbeli meghatározásához a következő képletet kell használnunk

$$
U_{B}=d_{t}^{x} S D_{y}^{x} A^{x} N^{x} t
$$

ahol $d_{t}$ a kvalitatív faktor standardizált megváltozása, $\mathrm{SD}_{\mathrm{y}}$ a kvalitatív faktor standardizált eltérésben elért egységnyi változás pénzben kifejezett értéke, A a kvalitatív faktor részesedése a munkahelyi teljesítményben (a teljesítmény teljes szórásából magyarázott rész), $\mathrm{N}$ az érintett dolgozók száma és t a hatás időbeli hossza. Cikkükben az SD együttható meghatározására különféle adatbázisok statisztikai vizsgálatát ajánlják, ugyanakkor hüvelykujj szabályként megjegyzik, hogy az érték jellemzően az átlagbér 20 és 80 százalék között van, az átlag pedig 40 százalék körül alakul.

E megközelítés lényegesen túllép a ROI korábban látott és kritizált képletén, hiszen az elért hatás időtartamát is figyelembe veszi. Ugyanakkor pénzügyileg aggályos, hogy az időértékkel nem számol, hiszen jelenérték számítása helyett a jövőbeli megtakarításokat egyszerűen összeadja, s így a becsléssel kapcsolatos bizonytalanságot sem lehet megjeleníteni az elvárt hozamban.

Egy brit biztosító, a Willis Group 2015-ös felmérése szerint az egészségprogramokat indító vállalatok 64 százaléka a VOI-szemléletre, míg 28 százaléka a ROI-szemléletre összpontosít (Pyrillis, 2016). A 2017-es Workplace Wellness Trends (SFM, 2017) jelentés is hasonló képet rajzol ki: a munkaadók negyedénél elsődleges cél az egészséggel kapcsolatos költségek csökkentése (a ROI-szemlélet), amikor egészségprogramot indítanak. A pénzügyi döntést követően ugyanakkor a vállalatok háromnegyede már a VOI-szemléletet figyelembe véve építi fel programját és követi nyomon annak hatásait.

Arról, hogy a VOI-szemléletben pontosan milyen mutatókra kellene figyelni, vagy azokat hogyan lehetne csoportosítani, egyelöre nincsen elfogadott elméleti keretrendszer. Ugyanakkor számos olyan kutatást ismerünk, amelyek egy-egy mért változó és a dolgozói teljesítmény között szoros, statisztikailag is szignifikáns kapcsolatot mutatott ki.

A WHO (2017) adatai szerint a vállalati egészségprogram három év alatt 27 százalékkal csökkenti a hiányzást. Márpedig ez komoly megtakarítást jelenthet a munkáltatónak. Serxner et al. (2001) 34451 egyesült államokbeli munkavállaló részvételével végzett kutatásában kimutatta: a mentális problémákkal küzdők 150, a hátfájósok 140, a munkahelyi stresszt átélők 131, a fizikailag inaktívak 118, a túlsúlyosak pedig 116 százalékkal vannak többet táppénzen, mint az átlag. Boles et al. (2004) szerint a fizikailag inaktívak és az egészségtelenül táplálkozók több mint másfélszer nagyobb eséllyel hiányoznak vagy dolgoznak betegen.

A British Gasnál a hátfájások miatt hiányoztak a legtöbbet a munkavállalók (ERS, 2016), így erre 300 résztvevőnek workshopokat szerveztek. Ezek eredményeképpen a hátfájások miatti hiányzások 43 százalékkal csökkentek és részvevőnként 1660 fontot spóroltak meg egy év alatt.

Harter et al. (2002) szerint a munkavállalói elköteleződés és a pénzügyi teljesítmény között közvetlen kapcsolat mutatható ki. A Gallup Intézet kutatásai szerint (WittersAgrawal, 2015) azon elégedett munkavállalók, akiknek a jól.léti pontszámai is magasak, 30 százalékkal kisebb valószínüséggel hiányoznak betegség miatt az elkövetkezendő egy hónapban azokhoz képest, akik bár elkötelezettek, de a jól-létük értékei alacsonyak. Éves szinten pedig 70 százalékkal kevesebb időt töltenek táppénzen.

Azon munkavállalók, akik a közepes vagy magas kockázati csoportba tartoznak étkezés vagy mozgás tekintetében, 6-12 százalékkal alacsonyabb teljesítményt nyújtanak, mint alacsony kockázatú társaik (Vaughan-Jones - Barham, 2009). Merrill et al. (2013) szerint azok, akik legalább 30 percet mozogtak minimum heti három napon és öt vagy annál több alkalommal gyümölcsöt és zöldséget fogyasztottak a megelőző négy napban, 1,2-szer nagyobb valószínüséggel nyújtottak nagyobb teljesítményt azoknál, akik ezt nem tették.

Azon vállalatok, amelyeknél nincs egészségprogram, négyszer nagyobb valószínüséggel veszítik el a legjobb dolgozóikat az elkövetkezendő 12 hónapban (VaughanJones - Barham, 2009). Egy brit szolgáltató cég 75 ezer fontot szánt arra, hogy életmódtanácsokat, fitnesz órákat és relaxációs gyakorlatokat kapjanak a helyszínen az alkalmazottjai. A fluktuáció 10 százalékkal csökkent, 464 ezer fontot spóroltak meg egy év alatt (ERS, 2016).

Egy bristoli kutatásban (Molnár, 2016) a rendszeresen mozgó irodai munkásoknak kellett a hangulatukat folyamatosan pontozniuk, valamint feljegyezniük, mikor edzettek. A résztvevők kedvezőbbnek ítélték hangulatukat azokon a napokon, amikor a munkakezdés előtt vagy napközben testmozgást végeztek. Az edzésnapokon 72 százalékuk könnyebben tudta beosztani idejét, 79 százalékuk javulást érzékelt a személyes kapcsolataiban, 74 százalékuk pedig könnyebben dolgozta fel a munka jelentette nyomást. Vaughan-Jones - Barham (2009) szerint 20 százalék csökkenés a lelki jól-lét mért értékeiben 10 százalékos teljesítménycsökkenéshez vezet. 
A VOI tehát nemcsak elvontabb és pénzben nehezebben mérhető eredményekre koncentrál, de szemlélete is más, inkább egyén és közösség, semmint vállalatközpontú. A balesetek, a hiányzásos napok száma, az el nem vesztett dolgozók száma és az egészségügyi költségek egyszerüen, könnyen mérhetőek, míg az egészségkockázat, a teljesítmény vagy termelékenység, az elégedettség, az alkalmazottak morálja nehezebben számszerüsíthető (Dorn, 2016). Ezek a tényezők ugyanakkor nagyban hozzájárulhatnak a szervezet egészségéhez és nyereségességéhez is (Haan, 2015).

A VOI tényezőit jóval nehezebb meghatározni, mérni, kiértékelni, mivel sok az önbevalláson alapuló, nagyrészt „puha” tényező, emiatt drágább, jellemzően kvalitatív mérések szükségesek az egyes összetevőinek nyomon követéséhez. Tudjuk, hogy a munkahelyi egészségprogramok hatással vannak az alkalmazottak moráljára, de csak nehezen számszerüsíthető ez a kapcsolat. Hogyan mérjük a csapat kohézióját? Hogyan értékeljük azokat a vállalati erőfeszítéseket, amelyeket az alkalmazottak megtartása érdekében végzünk? A VOI-szemlélet alkalmazásához a vállalati információs rendszert is fejleszteni kell, hiszen a cégek ritkán gyüjtenek adatot az alkalmazottak hangulatáról, jól-létéről, energiaszintjéről vagy éppen a presenteeismröl (Aldana, 2018d).

A WHAA (2016) modellje szerint elég a betegségeket, sérüléseket, termelékenységet mérni, mert ezek magukba foglalják a ,soft” tényezőket, úgymint a munkahelyi kultúra, morál, elköteleződés, energikusság, vonzás és megtartás hatásait. Nincs egységes, elfogadott mérési modell a nemzetközi irodalomban sem.

A dolgozói jól-létet például a Gallup Intézet által kifejlesztett jóllét-indexszel mérhetjük, amely öt tényezőt vizsgál. (Ez a módszer hasonlít a leginkább a Balanced Scorecard megközelítésére.) Meghatározza, hogy egyegy munkavállalónak (1) vannak-e céljai, szereti-e, amit csinál, illetve milyen a (2) szociális jól-léte, azaz megfelelő kapcsolatokkal rendelkezik-e. Ellenőrzik azt is, hogy a munkavállaló (3) anyagi biztonságban van-e, s (4) a közösség, a környék, a lakhelye megfelelö-e, illetve (5) fizikailag jól van-e, egészséges-e, energikus-e. Ebben a folyamatban különböző állításokat kell a munkavállalóknak önbevallással értékelni. Ugyancsak önbevallásos módon szokták az elégedettséget, elkötelezettséget, és sokszor még a teljesítményt is mérni. Erre már van hazai példa is: Barna és Fodor (2018) a Battlejungle nevű online alkalmazással a gemifikált megoldások hatását vizsgálták a munkahelyi légkör, a munkatársak közötti kapcsolat és a sportolási szokások változására. Mindhárom tényezőnél pozitív változásokat mutattak ki: a kutatásban résztvevők önbevallás alapján jobb munkahelyi légkörröl számoltak be és új embereket ismertek meg, kapcsolati hálójuk bővült, valamint ezen online külső motivációs eszköz segítségével sikerült belső késztetést ébreszteni a testmozgásra.
$\mathrm{Az}$ egészségprogramok megítélése ugyanakkor nem egységes. Osilla et al. (2012) 33 egészségprogramot bemutató publikációt tekintett át. Eszerint tényleg nemcsak és kizárólag pozitív hatása lehet az elindított programoknak, hanem az is előfordult, hogy nem értek el érzékelhető hatást az egyes tényezőknél. A programok értékelése során a hiányzás volt az egyetlen olyan tényező, amellyel kapcsolatban mindig pozitív változást mértek (3. táblázat). Egy-egy esetben előfordult, hogy a dohányzásra, az alkoholfogyasztásra, a mentális egészségre és az egészségügyi költségekre nem volt hatása az elindított egészségprogramnak (a program részleteinek ismerete nélkül ennek okát aligha lehet felderíteni). E kutatás szerint a legnehezebben a táplálkozási és mozgási szokások változtathatóak meg vállalati egészségprogramokkal.

3. táblázat

Az egyes programok értékelésének eredményei (programok száma)

\begin{tabular}{|l|c|c|}
\hline Az egészségprogram hatása & Pozitív hatás & Nincs hatás \\
\hline Mozgásra & 8 & 5 \\
\hline Táplálkozásra & 6 & 6 \\
\hline $\begin{array}{l}\text { BMI-re, koleszterinszintre, } \\
\text { vérnyomásra }\end{array}$ & 6 & 6 \\
\hline Dohányzásra & 6 & 1 \\
\hline Alkoholfogyasztásra & 2 & 1 \\
\hline Egészségügyi költségekre & 7 & 1 \\
\hline Hiányzásra & 4 & 0 \\
\hline Mentális egészségre & 3 & 1 \\
\hline
\end{tabular}

Forrás: Osilla et al. (2012)

\section{Az SROI-szemlélet}

A költség-haszon elemzésből kifejlődött társadalmi megtérülés (Social Return on Investment - SROI) az egészségügyi programok össztársadalmi hatását igyekszik megragadni (Banke-Thomas et al., 2015), elsősorban pénzbeli méréssel. Miközben a ROI-szemlélet kizárólag a vállalatot vizsgálja, a VOI-megközelítés pedig emellett az egyént és a vállalati munkaközösséget is, az SROI a befogadó társadalom minden érintettjét bevonja a vizsgálatba. E szemlélet alkalmazása elsősorban a közegészségügyi programoknál elterjedt, s használatának legnagyobb kihívását az érintettek körének megfelelő lehatárolása mellett az alkalmazandó időtáv helyes megválasztása jelenti. Bizonyos szempontból e megközelítés leszűkítése a VOI, amikor csak a hasznokból közvetlenül részesülő egyéneket és munkáltatójukat vizsgáljuk, ugyanakkor a pénzbeli mérésre törekvés a VOInál szűkebb lehetőségeket kínál. Az SROI az egészségügy hagyományos teljesítmény mutatóival szemben azért jelent előrelépést, mert nem csupán az egészségügyi hozamokat fedi le, hanem kiterjed valamennyi társadalmi, gazdasági és környezeti elönyre is (4. táblázat). 
4. táblázat

A szakirodalomban előforduló mérési megközelítések

\begin{tabular}{|l|c|c|}
\hline \multirow{2}{*}{$\begin{array}{c}\text { Az előnyök } \\
\text { mérésének fókusza }\end{array}$} & \multicolumn{2}{|c|}{ Alkalmazott mutatók } \\
\cline { 2 - 3 } & $\begin{array}{c}\text { Csak pénzügyi } \\
\text { mutatók (CBA) }\end{array}$ & $\begin{array}{c}\text { Pénzügyi és } \\
\text { nem pénzügyi } \\
\text { mutatók (CEA) }\end{array}$ \\
\hline $\begin{array}{l}\text { A költségeket fedező } \\
\text { szervezet }\end{array}$ & ROI & \\
\hline $\begin{array}{l}\text { Részt vevő egyének, } \\
\text { közösség }\end{array}$ & & VOI \\
\hline Az egész társadalom & SROI & \\
\hline
\end{tabular}

Forrás: saját szerkesztés

Millar és Hall (2018) konkrét képletet is megad az SROI számításra, amely lényegében a pénzügyben ismert jövedelmezöségi rátával (profitability index - PI) azonos:

$$
\text { SROI }=\frac{\text { Várható hozamok nettó jelenértéke }}{\text { Befektetések nettó jelenértéke }}
$$

Ennek a rátának a pénzügyben számos előnye van, ugyanakkor gyakran felhozott kritika, hogy az időigényt nem vizsgálja, ezért az eltérő futamidejü programok és projektek összevetésére nem alkalmas. Ha azonban eltérö élettartamú alternatívák összevetésre nem használjuk, csupán csak azt vizsgáljuk, hogy egy adott projektet gazdaságilag racionális-e megvalósítani, a mutató jól alkalmazható és az egy feletti érték megkövetelése elegendö lehet.

Leck et al. (2018) részletesen bemutatja az SROI-megközelítés gyakorlati alkalmazását. Kiemelik: hét alapelvet kell a folyamat során szem elött tartani. Ezek szerint (1) minden érdemi érintettet be kell vonni, (2) valamennyi hatást fel kell tárni, (3) a ténylegesen igazolható hatásokat ki kell választani, (4) és csak a fontos hatásokat kell értékelni. (5) El kell kerülni a hatások felülbecslését, (6) meg kell örizni az átláthatóságot és (7) az eredményeket ellenőrizni is kell.

A folyamat során az első lépés az érintettek azonosítása, amelyet a következmények feltárása követ. Ezt követően igazolni kell az ok-okozati kapcsolatot, és megfelelő pénzbeli becsléseket használva értékelni kell a hatásokat. Az SROI számszerüsítése után nemcsak meg kell osztani az eredményeket, de a döntésekbe be is kell építeni azokat.

A hatások pénzbeli mérése okozta gondot a fizetési hajlandóság mérésével, vagy az elkerülendő állapot elfogadásáért kért kompenzációval javasolják mérni. A közérzet és a boldogságszint javulásához társított pénzbeli értéket úgy is meg lehet határozni, hogy statisztikai módszerekkel nagy társadalmi adatbázisokból megbecsülik, hogy hasonló boldogságnövekedést mekkora jövedelememeléssel lehetne elérni. Így például korábbi kutatások alapján a munkával való elégedettség egy ponttal való megemelke- dése egy 10 pontos skálán 36 százalékos jövedelemnövekedésnek felelt meg.

Banke-Thomas et al. (2015) a szakirodalomban talált kellően dokumentált 44 SROI-alkalmazást vizsgálva rámutat: miközben az utólagos értékeléseket átlagosan egy év és tizenegy hónap után hajtották végre, a programok átlagos időhorizontja kilenc év és öt hónap volt. Ezek alapján lényeges észrevennünk, hogy a kapott eredményeket nem lehet érdemben összevetni sem a projektek között, sem pedig tény-terv viszonylatban. A hosszú programoknál (a tervek időtartama 1 és 30 év közé esett) a pénz időértékének helyes kezelése is kulcsfontosságú és egyebek mellett az inflációs hatások sem elhanyagolhatóak. (Az egységes módszertan nélkül közvetlenül nehézkesen összevethető szakirodalmi eredményeket az 5. táblázat mutatja, a legnagyobb szórás és a legnagyobb lehetséges társadalmi hatás is a gyermekgyógyászat és a szexuális egészség területén tapasztalhatók, miközben a kutatás szerint a táplálkozás vagy az egészségnevelés társadalmi megtérülése alacsonyabb.)

5. táblázat

Közegészségügyi programok SROI értékei

\begin{tabular}{|l|c|c|}
\hline Egészségügyi terület & $\begin{array}{c}\text { Legkisebb } \\
\text { SROI }\end{array}$ & $\begin{array}{c}\text { Legmagasabb } \\
\text { SROI }\end{array}$ \\
\hline Gyermekgyógyászat & 1,85 & 65,00 \\
\hline Környezeti hatások* & 26,00 & 26,00 \\
\hline $\begin{array}{l}\text { Egészségügyi } \\
\text { menedzsment }\end{array}$ & 1,98 & 7,00 \\
\hline Egészségnevelés* & 7,25 & 7,25 \\
\hline $\begin{array}{l}\text { Egészséges életmód } \\
\text { népszerüsítése }\end{array}$ & 1,10 & 11,00 \\
\hline Lelki egészség & 1,57 & 11,91 \\
\hline Táplálkozás & 2,05 & 5,28 \\
\hline Szexuális egészség & 1,73 & 21,20 \\
\hline \multicolumn{2}{|l|}{ *Egyetlen vizsgált cikk }
\end{tabular}

Forrás: Banke-Thomas et al. (2015) alapján

Leck et al. (2018) megmérte az általuk vizsgált program előnyeinek érintettek közti megoszlását is. Eszerint a közvetlenül a programban résztvevők az előnyök 61 százalékát realizálták, míg rokonaik, ismerőseik 18 százalékot. A társadalombiztosítás terheinek csökkenése további 17 százalékot fedett le a teljes haszonból.

A három eltérő megközelítés sajátosságait a 6. táblázat foglalja össze. A különböző módszertanok eredményeinek összevetésére szemléletes példát ad Lin et al. (2017). Becsléseik szerint egy amerikai honvédségi egészségprogram ROI-szemléletben 1 dollár költéssel 1,81 dollárnyi megtakarítást okozott. Ugyanakkor tágabb kontextusban (lényegében a VOI-szemléletet követve) már 2,49 dollárt tettek ki a hasznok. 
6. táblázat

ROI, VOI és az SROI szemlélet összevetése

\begin{tabular}{|c|c|c|}
\hline Szemlélet & Célok, hatások & Adatok mérése, számszerűsíthetősége \\
\hline ROI & $\begin{array}{l}\text { Az egészségügyi kiadások csökkentése } \\
\text { Betegnapok számának csökkentése } \\
\text { Sérülések miatti kiadások csökkentése }\end{array}$ & $\begin{array}{l}\text { - pénzben könnyen mérhető } \\
\text { - könnyen elérhető és értékelhető adatok } \\
\text { - orvosi kiadások/megtakarítások (hiányzások, } \\
\text { betegségek és sérülések) figyelembe vételére } \\
\text { koncentrál } \\
\text { - az eredmények módszertanilag nem } \\
\text { kifogásmentesek }\end{array}$ \\
\hline VOI & $\begin{array}{l}\text { Egészségügyi kockázatok csökkentése, } \\
\text { egészségtudatosság növelése } \\
\text { Munkavállalói elégedettség növelése } \\
\text { A termelékenység, az üzleti teljesítmény, } \\
\text { jövedelmezőség növelése } \\
\text { Morál fejlesztése } \\
\text { Tehetséges alkalmazottak vonzása, megtartása, } \\
\text { fluktuáció csökkentése } \\
\text { Munkavállalók energia szintjének növelése } \\
\text { Növelni a munkahelyi biztonságot } \\
\text { Munkahelyi kohézió, csapatmunka javítása } \\
\text { Presenteeism csökkentése } \\
\text { Jól-lét, munkavállalói jóérzések növelése }\end{array}$ & $\begin{array}{l}\text { - a program teljes összértékét vizsgálja } \\
\text { - nehezebben mérhető, ,,puhább” tényezők } \\
\text { - a vállalati információs rendszer fejlesztését igényli } \\
\text { - az adatok különböző vállalati egységeknél vannak, } \\
\text { nehéz integrálni, elemezni ezeket } \\
\text { - jórészt nem pénzbeli mérésekre támaszkodik, sok } \\
\text { az önbevallásos adat, } \\
\text { - inkább kvalitatív, mint kvantitatív kutatásokkal } \\
\text { meghatározhatók }\end{array}$ \\
\hline SROI & $\begin{array}{l}\text { Társadalmi jól-lét maximalizálása } \\
\text { A rendelkezésre álló költségvetés optimális elköltése } \\
\text { Adott egészségügyi cél eléréséhez legmegfelelőbb } \\
\text { program kiválasztása }\end{array}$ & $\begin{array}{l}\text { - a társadalmi hasznosság maximalizálása, } \\
\text { a megelőző programok kezeléssel és gyógyítással } \\
\text { szembeni elönyeinek bemutatása a cél } \\
\text { - pénzbeli mérésre törekszik } \\
\text { - komoly etikai kihívásokat támaszthat (az emberi } \\
\text { élet és egészség pénzbeli mérése) }\end{array}$ \\
\hline
\end{tabular}

Forrás: Aldana (2018d), Banke-Thomas et al. (2015) és Sendi (2008) alapján

Sendi (2008) ugyanakkor a pénzügyi módszerek egészségügyi területen való alkalmazása kapcsán korábbi cikkekre hivatkozva kiemeli az etikai kérdések fontosságát. Ha pusztán különféle hozamok alapján választunk alternatívák közül, könnyen lehet, hogy a könnyebben befolyásolható viselkedés vagy a kisebb gondokkal küszködők kiemelt figyelmet (prémium ellátást) kapnak, míg mások teljesen kimaradnak a programokból. Elég csak azt fontolóra vennünk, hogy a megváltozott munkaképességűek igényeire szabott egészségprogramok költségei hogyan viszonyulhatnak az azonos eredményt egészségeseknél elérő megoldásokéhoz. Úgy tünik tehát, hogy a bemutatott három szemlélet kizárólagos követése még egy üzleti vállalkozásnál is konfliktust okozhat a társadalmi felelősségvállalás elveivel.

\section{Módszertani problémák}

Miközben a VOI-szemléletü mérés nagyon sok szubjektív elemet tartalmaz, ráadásul komoly fejlesztéseket igényel és időigénye is nagyobb a ROI-szemléletű megközelítésnél, koránt sem igaz, hogy ez utóbbi minden problémától mentes volna. Például Nicholson (2017) több mint tíz ilyen kihívást is említ a korábban látott definíciós és pénzügyi szemlélettől elszakadt mérési technikák mellett.

A mérés során felmerülnek (1) statisztikai kérdések. A kiértékeléskor gyakran az adatok normális eloszlását feltételezik, miközben az alapsokasági eloszlás sokszor nem ismert, a programokban való részvétel pedig önkéntes, így a minta nem véletlen. Ezt Dongen et al. (2011) is nehezményezi.

(2) Kontrollcsoport hiányában az elért megtakarítások csak a múlthoz képest számszerüsíthetőek, vagyis nem tudható biztosan, hogy valamennyi változás az egészségprogram bevezetésének köszönhetö.

(3) Jelentős lehet a kiválasztási torzítás is. Az önkéntes résztvevők nagyon motiváltak, emiatt a kapott eredmények felülbecsülhetik azt a pozitív hatást, amelyet valamennyi munkavállaló bevonásakor érhetnénk el. Erröl a felülbecslésröl Dongen et al. (2011) és Baxter et al. (2014) is írnak.

(4) A viselkedési torzítás (amelyet a pénzügyben másutt túlélési torzításnak is neveznek) ugyancsak erősen befolyásolja az eredményeket. Azok a résztvevők, akik nem változtatják meg a viselkedésüket vagy kilépnek a programból, kikerülnek a mintából is. Ezért csak azokat a dolgozókat vizsgálják, akik változtattak, amivel túlbecsülhetik a program eredményeit.

(5) A Hawthorne-hatásról sem szabad megfeledkeznünk. A megfigyelésben résztvevők megváltoztathatják a magatartásukat és másképpen érezhetik magukat egyszerüen azért, mert vizsgálják őket és kíváncsiak rájuk. Nana et al. (2002) kutatásai szerint például a Canadian Life Assurance vállalatnál 7 százalékkal nagyobb lett a termelékenység az egészségprogram résztvevői között, ugyanakkor 4 százalékkal nagyobb termelékenység volt kimutatható a programban nem résztvevőknél is. 
(6) Ha van kontrollcsoport, előfordulhat az információk diffúziója is. Mivel a vizsgált csoportban és a kontrollcsoportban dolgozók gyakran ugyanazon a munkahelyen dolgoznak, bizonyos információk és hatások átszivároghatnak a kontrollcsoportba is, és így a kimutatható különbségek csökkennek.

(7) A hatások sok esetben szubjektívek. Sok munkahely nem rendelkezik könnyen mérhető teljesítménnyel, a termelékenység mérésére és értékére szolgáló módszerek nagymértékben változóak. Számos tanulmány, amely a termelékenység és a teljesítmény javulásáról ír, önálló és szubjektív értékelésekre támaszkodik. Ozminkowski et al. (2016) kutatásai szerint mindössze a kutatásban részt vett vállalatok 34 százaléka mérte a termelékenység tényleges változását. A WHAA (2016) azt javasolta, hogy inkább külsős értékeljen, mert a belsős elfogult és érdekelt a minél nagyobb javulás kimutatásában.

(8) A vizsgálatok hossza is gondot okozhat. Sok tanulmány túl rövid időtartamot vizsgál, így nem tudni, hogy az egészségfejlesztési beavatkozások hosszú távon milyen fajta és mértékű magatartásváltozáshoz vezetnek. Bizonyos beavatkozásoknál a költségek azonnal felmerülnek, de a hasznok sokkal később realizálódnak, a tartósságuk pedig nem mindig bizonyítható. Dongen et al. (2011) is hangsúlyozta, hogy a költségek kezdetben nagyobbak, míg az egészségelőnyök fokozatosan jelentkeznek.

(9) A munkahelyi egészségprogramok gazdasági elemzési eredményei nagyrészt az Egyesült Államokból származnak. A tizenegy európai program, amelyre a közelmúltban végeztek szisztematikus vizsgálatokat, nagyrészt nem mutatott pozitív gazdasági hatásokat.

(10) Nehézkes az egyes részelemek hatásának mérése is. Lehetetlen költségmegtakarítást meghatározni egy széles körü programon belüli konkrét intézkedésekre, ráadásul a külső tényezők is változnak, nincs ceteris paribus (minden más tényező változatlansága melletti) elemzésre lehetöség. Az immateriális elönyök pedig még inkább problémássá teszik a mérést.

(11) Publikációs torzításokat is tapasztalhatunk. A sikertelen és veszteséges programok jóval kisebb publicitást kapnak, hiszen a megvalósítóknak nem érdeke a nyilvánosság. Erről szintén olvashatunk Dongen et al. (2011) és Baxter et al. (2014) kutatásaiban.

E problémákhoz hozzászámíthatjuk nemcsak a már látott etikai és definíciós kérdéseket, de célszerü emlékezni arra is, hogy a hatékonyság mutatók minden esetben a nevezőben lévő input (jellemzően a rendelkezésre álló pénzmennyiség) szükösségét teszik fel. Ugyanakkor, ha egy időben több korlátos erőforrásunk is van (szervezésre áldozható munkaidő, emberi erőforrás, részvételre használható szabadidő, elérhető eszközkapacitás), pusztán e mutatók segítségével nem lehet az optimális programszerkezetről dönteni. Ehelyett egy többváltozós optimum számítási problémát kell megoldanunk, amely egyszerü hányadosok helyett lineáris programozást igényelhet. A WHAA (2016) abban látja a megoldást, hogy a módszertani minőségre ki kell fejleszteni egy skálát, az eddigi kutatások értékelésére, ami egyfajta ,standardként” is szolgálhat a jövőbeli kutatásokhoz.

\section{Összegzés}

A munkahely kiváló terepe az egészségre nevelésnek. A munkahelyi egészség egy olyan win-win-win szituáció, amely nemcsak az egyénnek és a vállalatnak teremt értéket, de közvetett módon a társadalom is profitál belőle. Globális szinten egyre több vállalatnál üzletileg megtérülő befektetésként kezelik e programokat.

Miközben a ROI-szemlélet jegyében kizárólag a cég szempontjából elemezve azt vizsgálják, hogy hány dollárt takarított meg a vállalat minden egyes egészségfejlesztésbe befektetett dollárjával, addig a VOI-szemlélet szintén a vállalkozás szemszögéböl, de alapvetően az összes értékteremtő tényező változását méri, nem feltétlenül pénzben. Míg a balesetek, a hiányzásos napok száma, az egészségügyi költségek egyszerüen, könnyen mérhetőek, a VOI-szemléletben fontos egészségkockázat, teljesítmény, termelékenység, elégedettség, az alkalmazottak morálja, elköteleződése és jól-léte nehezen nyomon követhető.

Az egészségügyi költség-haszon elemzésekből kifejlödött SROI-szemlélet még a VOI-nál is szélesebb kört ölel fel, s a nézőpontja is eltérő. Akár az egész társadalmat tekinti érintettnek, ugyanakkor szinte kizárólag pénzbeli mérésre törekszik. Ennek megfelelően jóval nagyobb megtérülést mutathat ki, azonban olyan mennyiségeket igényelhet (emberi élet, betegségek elkerülése, gyógyítása, termékenységi ráta növekedése), amelyek pénzbeli mérése súlyos etikai dilemmákat is felvethet.

\section{Felhasznált irodalom}

Aldana, S. G. (2001): Financial impact of health promotion programs: a comprehensive review of the literature. American Journal of Health Promotion, 15(5), p. 296320. DOI:10.4278/0890-1171-15.5.296

Aldana, S. G. (2018a): How much does an employee wellness program cost? https://www.wellsteps.com/ blog/2018/01/07/employee-wellness-program-cost/, Letöltés: 2018. február 8.

Aldana, S. G. (2018b): 5 Workplace Wellness Statistics Every Employer Should Know. https://www.wellsteps. com/blog/2018/01/06/workplace-wellness-statisticswellness-stats/, Letöltés: 2018. február 8.

Aldana, S. G. (2018c): 7 Reasons Workplace Health Promotion Programs Work. https://www.wellsteps.com/ blog/2018/01/12/workplace-health-promotion-programs/, Letöltés: 2018. február 8.

Aldana, S. G. (2018d): Wellness ROI vs VOI: The Best Employee Wellbeing Programs Use Both. https:/www. wellsteps.com/blog/2018/01/10/wellness-roi-employee-wellbeing-programs/, Letöltés: 2018. február 8.

Aon Hewitt (2017): 2017 Trends in Global Employee Enga $\neg$ gement. http://www.aon.com/attachments/human-ca-pital-consulting/2017-trends-inglobalemployee-en $\neg$ gagement-report.pdf, Letöltés: 2018. augusztus 31 .

Bácsi, K. (2017): Miért és mikor jó a bevonás? - érvek munkáltatói és munkavállalói oldalon. Vezetéstudomány/Budapest Management Review, 48 (8-9), p. 13-21. DOI https://doi.org/10.14267/VEZTUD.2017.09.02 
Baicker, K. - Cutler, D. - Song, Z. (2010): Workplace wellness programs can generate savings. Health Affairs, 29(2), p. 304-311. DOI: 10.1377/hlthaff.2009.0626

Banke-Thomas, A. - Madaj, B. - Charles, A. - van den Broek, N. (2015): Social Return on Investment (SROI) methodology to account for value for money of public health interventions: a systematic review. BMC Public Health, 15(1), p. 1-14. DOI: 10.1186/s12889-015-1935-7

Barna, B. - Fodor, Sz. (2018) Gamifikált közösségi megoldás használata a kedvezőbb munkahelyi légkör kialakítása érdekében. Vezetéstudomány/Budapest Management Review, 49 (3), p. 2-10. DOI https://doi. org/10.14267/VEZTUD.2018.03.01

Baxter, S. - Sanderson, K. - Venn, A. J. - Blizzard, C. L. - Palmer, A. J. (2014): The relationship between return on investment and quality of study methodology in workplace health promotion programs. American Journal of Health Promotion, 28(6), p. 347-363. DOI: 10.4278/ajhp.130731-LIT-395.

$B C G$ (2018): Decoding Global Talent 2018, https:/www. bcg.com/publications/2018/decoding-global-talent. aspx, Letöltés: 2018. augusztus 30.

Boles, M. - Pelletier, B. - Lynch, W. (2004): The relationship between health risks and work productivity. Journal of Occupational and Environmental Medicine, 46(7), p. 737-745. DOI: 10.1097/01.jom.0000131830.45744.97

Brealey, R. A. - Myers, S. C. - Franklin, A. (2011): Principles of corporate finance. New York: McGraw-Hill

Casey, J. C. (2017): Employee Well-being: A Comprehensive Approach Enhancing the Employee Experience and Business Outcomes. Chestnut Hill: Boston College Center for Work and Family

Chu, C. - Driscoll, T. - Dwyer, S. (1997): The health-promoting workplace: an integrative perspective. Australian and New Zealand Journal of Public Health, 21(4), p. 377-385. DOI: 10.1111/j.1467-842X.1997.tb01718.x

Coca-Cola (2013): Coca-Cola Magyarország CSR 2013 Rövid jelentés, https://hu.coca-colahellenic.com $/$ hu/m\%C3\%A 9 dia/jelent $\%$ C3\%A 9 sekkiadv\%C3\%A 1 nyok-esettanulm\%C3\%A 1 nyok/ coca-cola-hbc-magyarorsz $\% \mathrm{C} 3 \% \mathrm{~A} 1 \mathrm{~g}$-csr-roevidjelent\%C3\%A9s-2013/, Letöltés: 2018. március 1.

Culyer, A. J. - Chalkidou, K. (2018): Economic Evaluation for Health Investments En Route to Universal Health Coverage: Cost-Benefit Analysis or Cost-Effectiveness Analysis? Value in Health. doi:10.1016/j. jval.2018.06.005.

Dongen, J. M. - Proper, K. I. - Van Wier, M. F. - Van der Beek, A. J. - Bongers, P. M. - Van Mechelen, W. - Van Tulder, M. W. (2011): Systematic review on the financial return of worksite health promotion programmes aimed at improving nutrition and/or increasing physical activity. Obesity Reviews , 12(12), p. 1031-1049. DOI: 10.1111/j.1467-789X.2011.00925.x.

Dorn, D. (2016): How to Show Value of Investment in Wellness Programs, https://dorncompanies.com/wellness-programs-value/, Letöltés: 2018. január 10.

Eichberg, H. (2009): Organising sport around the workplace: Some experiences from Scandinavian company sport. Physical Culture and Sport - Studies and Research, 46(1), p. 130-136. DOI: https://doi.org/10.2478/ v10141-009-0011-3

ENWHP (1997): Luxembourg Declaration on Workplace Health Promotion in the European Union. http://www. workrelax.it/content.172.enwhp_luxembourg_declaration_on_workplace_health_promotion_in_the_european_union.html, Letöltés: 2018 . január 10.

ERS (2016): Health at Work: Economic Evidence Report 2016. https://www.bhf.org.uk/-/media/files/healthat-work/health_at_work_economic_evidence_report_2016.pdf., Letöltés: 2017. november 1.

EU-OSHA (2018): Prevention of work-related diseases. https://osha.europa.eu/en/highlights/preventionwork-related-diseases-eu-osha-launches-new-website-section?pk_campaign=OSHmail\%2003\%202018., Letöltés: 2018. március 10.

Eurostat (2018): Gross domestic product at market prices. https://ec.europa.eu/eurostat/tgm/table.do?tab=table \&init $=1 \&$ language $=$ en $\&$ pcode $=$ tec $00001 \&$ plugin $=1$, Letöltés: 2018. szeptember 30.

Fritz, S. - Richter, P. (2018): Effektivität und Nutzen betrieblicher Gesundheitsförderung Wie lässt sich beides sinnvoll messen? Pravention Und Gesundheitsforderung 6 (2), p. 124-130. doi:10.1007/s11553-010-0271-0.

Géring, Zs. (2014) Profit és/vagy közösségi szerepvállalás? Vállalati társadalmi felelősségvállalás vezetői szemmel. Vezetéstudomány/Budapest Management Review, 45 (12), p. 53-66.

Goetzel, R. Z. - Roemer, E. C. - Liss-Levinson, R. C. Samoly, D. K. (2008): Workplace Health Promotion: Policy Recommendations that Encourage Employers to Support Health Improvement Programs for their Workers. http://prevent.org/data/files/initiatives/workplacehealtpromotion-policyrecommendations.pdf., Letöltés: 2017. november 1.

Goetzel, R. Z. - Shechter, D. - Ozminkowski, R. J. - Marmet, P. F. - Tabrizi, M. J. - Roemer, E. C. (2007): Promising practices in employer health and productivity management efforts: findings from a benchmarking study. Journal of Occupational and Environmental Medicine, 49(2), p. 111-130. DOI: 10.1097/ JOM.0b013e31802ec6a3

Goetzel, R. Z. (2016): What is the latest research in workplace health promotion? In: 2016 HERO Forum Conference Proceedings, http://hero-health.org/publication/hero-forum-2016-proceedings/, Letöltés: 2017. november 1.

Haan, W. S. (2015): VOI data for workplace wellness captures intangibles that ROI does not. https:/www.hopehealth.com/voi-data-workplace-wellness-capturesintangibles-roi-not/, Letöltés: 2017. január 10.

Hackbarth, N. - Brown, A. - Albrecht, H. (2015): The whole employee matters. https://www.limeade.com/2015/04/ the-whole-employee/, Letöltés: 2017. január 10.

Harter, J. K. - Schmidt, F. L. - Hayes, T. L. (2002): Business-unit-level relationship between employee satisfaction, employee engagement, and business outcomes: a meta-analysis. Journal of Applied Psychology, 87(2), p. 268-279. 
Henke, R. M. - Goetzel, R. Z. - McHugh, J. - Isaac, F. (2011): Recent experience in health promotion at Johnson \& Johnson: lower health spending, strong return on investment. Health Affair, 30(3), p. 490-499. DOI: 10.1377/hlthaff.2010.0806.

International Organization for Standardization (2018): ISO 31000 - Risk management. https://www.iso.org/iso31000-risk-management.html, Letöltés: 2018. március 11.

Johns Hopkins Bloomberg School of Public Health (JHBS) (2015): From Evidence to Practice: Workplace Wellness that Works. https://www.transamericacenterforhealthstudies.org/docs/default-source/wellness-page/ from-evidence-to-practice---workplace-wellness-thatworks.pdf?sfvrsn=2., Letöltés: 2017. március 1.

KSH (2018): A bruttó hazai termék (GDP) értéke forintban, euróban, dollárban, vásárlóerő-paritáson (1995-). http://www.ksh.hu/docs/hun/xstadat/xstadat_eves/i_ qpt015.html, Letöltés: 2018. szeptember 30.

Leck, C. - Evans, N. - Upton, D. (2018): Social Return on Investment: Valuing Health Outcomes or Promoting Economic Values? Journal of Health Psychology, 21 (7), p. 1481-1490. doi:10.1177/1359105314557502.

Lin, A. H. - Welstead, B. L. - Morey, B. L. - Mahnke, B. Cole, J. - Johnston, M. (2017): Return on Investment Analysis of Health Experts onLine at Portsmouth: A 2-Year Review of the Navy's Newest Teleconsultation System'. Military Medicine, 182(5), p. 1696-1701. DOI: 10.7205/MILMED-D-16-00259.

Mattke, S. - Liu, H. - Caloyeras, J.P. - Huang, C.Y. - Van Busum, K.R. - Khodyakov, D. - Shier, V. (2013): Workplace Wellness Programs Study Final Report. Santa Monica: RAND Corporation

Meretei, B. (2017) Generációs különbségek a munkahelyen - szakirodalmi áttekintés. Vezetéstudomány/ Budapest Management Review, 48 (10), p. 10-18. DOI https://doi.org/10.14267/VEZTUD.2017.10.02

Merrill, R. M. - Aldana, S. G. - Pope, J. E. - Anderson, D. R. - Coberley, C. R. - Grossmeier, J. J. - Whitmer, $R$. W. (2013): Self-rated job per $\neg$ formance and absenteeism according to employee en $\neg$ gagement, health behaviors, and physical health. Journal of Occupational and Environmental Medicine, 55(1), p. 10-18. DOI: 10.1097/JOM.0b013e31827b73af

MGYOSZ (2010): Az egészséges munkavállalókért és a biztonságos munkahelyekért. www.euromenedzser. hu/hu/kiadvanyaink, Letöltés: 2013. november 1.

Millar, R. - Hall, K. (2018): Social Return on Investment (SROI) and Performance Measurement: The Opportunities and Barriers for Social Enterprises in Health and Social Care. Public Management Review, 15 (6), p. 923-941. doi:10.1080/14719037.2012.698857.

Molnár, Cs. (2016): A sport esete a stresszel: tényleg csökkenti? https://mno.hu/tornasor/a-sport-esete-a-stresszeltenyleg-csokkenti-1326121, Letöltés: 2017. május 30.

Nana, G. - Sanderson, K. - Goodchild, M. (2002): Economic impact of sport. Wellington: Business and Economic Research Ltd.

Nicholson, P. J. (2017): Employee wellbeing programmes and return on investment: the false profit. In Research,
Occupational Health, Wellbeing and Health Promotion, Wellbeing, https://www.personneltoday.com/hr/ employee-wellbeing-programmes-return-investmentfalse-profit/, Letöltés: 2018. január 10.

Oliveira, K. - Méxas, M. - Meiriño, M. - Drumond, $G$. (2018): Critical success factors associated with the implementation of enterprise risk management. Journal of Risk Research, p. 1-16, DOI: 10.1080/13669877.2018.1437061

Osilla, K. C. - Van Busum, K. - Schnyer, C. - Larkin, J. W. - Eibner, C. - Mattke, S. (2012): Systematic review of the impact of worksite wellness programs. American Journal of Managed Care, 18(2), p. 68-81.

Ozminkowski, R. J. - Serxner, S. - Marlo, K. - Kichlu, R. - Ratelis, E. - Meulebroecke, J. V. (2016): Beyond ROI: Using Value of Investment to Measure Employee Health and Wellness. Population Health Management, 19(4), p 227-229. https://doi.org/10.1089/pop.2015.0160

Pfeffer, J. (2018): Dying for a Paycheck. How Modern Management Harms Employee Health and Company Performance - and What We Can Do About It. Stanford: Harper Business

Pyrillis, R. (2016): Welcome to wellness 2.0. https://www. limeade.com/press/welcome-to-wellness-2-0/, Letöltés: 2018. január 10.

Sendi, P. (2008): Bridging the Gap between Health and Non-Health Investiments: Moving from Cost-Effectiveness Analysis to a Return on Investment Approach across Sectors of Economy. International Journal of Health Care Finance and Economics, 8(2), p. 113-121. DOI: $10.1007 / \mathrm{s} 10754-008-9032$

Serxner, S. - Gold, D. B. - Bultman, K. K. (2001): The impact of behavioral health risks on worker absenteeism. Journal of Occupational and Environmental Medicine, 43(4), p. 347-354.

SFM (2017): ROI and VOI: A strong wellness program measures both. https://www.sfmic.com/roi-and-voia-strong-wellness-program-measures-both/, Letöltés: 2018. január 10.

Springbuk (2018): How to Measure ROI on Corporate Wellness Programs. https://www.springbuk.com/measure-roi-on-corporate-wellness-programs/, Letöltés: 2018. szeptember 30 .

Szabó, Á. (2018): Eredményjelzés a munkahelyi sportról, a "Legfittebb Munkahely Felmérés" első éveinek tapasztalatai. Magyar Sporttudományi Szemle, XIX. évfolyam, 73. szám, p. 25-31.

Szabó, Á. (2013): Munkahelyi egészségfejlesztés, munkahelyi sport, elméleti megközelítés. Magyar Sporttudományi Szemle, XIV.évf. 56., p. 56-65.

Szinapszis (2013): Már a munkahelyen is számít az egészség. http://www.webbeteg.hu/cikkek/egeszseges/ 14720/mar-a-munkahelyen-is-szamit-az-egeszseg, Letöltés: 2013. augusztus 10.

Tasmania (2012): Your Simple Guide to Workplace Health and Wellbeing. http://worksafe.tas.gov.au/_data/ assets/pdf_file/0003/252390/Your_Simple_Guide to_Workplace_Health_and_Wellbeing.pdf., Letöltés: 2015. január 11 . 
Thorpe, A. (2015): The 44 Healthiest Companies to Work for in America, https:/greatist.com/health/healthiestcompanies, Letöltés: 2018. augusztus 30.

Vaughan-Jones, H. - Barham, L. (2009): Healthy Work Challenges and Opportunities to 2030. London: Press Office Bupa

Virgin Pulse (2016): The Business of Healthy Employees: A Survey of Workplace Health Priorities. http://community.virginpulse.com/business-of-healthy-employees-2016-survey-web, Letöltés: 2017. március 1.

Virgin Pulse (2017): A 2017 Survey of Workplace Health Priorities. https://cdn2.hubspot.net/hubfs/285174/ Business OfHealthyEmployees.VirginPulse.2017. pdf?t=1518459945606., Letöltés: 2018. március 1.

WHAA (2016): ROI White Paper. Workplace Health Association of Australia
WHO (2010): Healthy Workplace Framework and Model. www.who.int/occupational_health/ healthy_workplace framework.pdf, Letöltés: 2013. július 1.

WHO (2017): Protecting workers' health. http://www.who. int/mediacentre/factsheets/fs389/en/, Letöltés: 2018. február 28.

Witters, D. - Agrawal, S. (2015): Well-Being Enhances Benefits of Employee Engagement. Business Journal, October 27, http://news.gallup.com/businessjournal/186386/enhances-benefits-employee-engagement. aspx, Letöltés: 2018. február 28.

Xerox (2016): Working Well: A Global Survey of Workforce Wellbeing Strategies 2016 - Survey report, 7th ed.. http://www.globalhealthyworkplace.org/casestudies/2016_Global_Wellbeing_Survey_ExecutiveSummary.pdf, Letöltés: 2018. február 10. 